\title{
Emotional Intelligence and Autonomous Learning in Student Cyberbullying in Times of Covid-19
}

\author{
Marlene Domitila Loayza Claudio ${ }^{1}$, Edward Flores ${ }^{1}$ \\ ${ }^{1}$ Universidad Cesar Vallejo
}

Article History: Received: 10 November 2020; Revised 12 January 2021 Accepted: 27 January

2021; Published online: 5 April 2021

\begin{abstract}
The research entitled: "Emotional intelligence and autonomous learning in cyberbullying of students of the Educational Institution" Francisco Bolognesi ", 2020", aimed to determine the incidence of emotional intelligence and autonomous learning in cyberbullying, and responds to the problem institutional educational. The study is explanatory, obeys a quantitative approach and a non-experimental, causal correlational, cross-sectional design; with a sample comprised of 99 students, to whom questionnaires were applied to collect data on each of the variables. After the analysis and interpretation of the results, the following conclusion was reached: Emotional intelligence and autonomous learning had a significant impact on cyberbullying of the students of the "Francisco Bolognesi" Educational Institution in Villa el Salvador; having obtained a result in the linear logistic regression test $\mathrm{p}$-value $=0.000$.
\end{abstract}

Keywords: Emotional intelligence, autonomous learning, cyberbullying, interpersonal relationships.

\section{Introduction}

Living together democratically became a prevailing need in the 21 st century. In the educational field, the issue is included in the projects of each institution dedicated to this service and in the proposed management guidelines proposed by the Ministry of Education. When observing the current problematic reality, different conflicts between schoolchildren were evidenced, faced with this, the difficult task is assumed that students can work in an environment of harmony and respect with little successful results, even more so today since education is It has been developing virtually due to the COVID-19 pandemic.

For Martínez (2018), at first glance the indifference of students to ask questions allows us to identify deficiencies in autonomous learning, this recurring fact is directly related to their behavior, there are influential factors that induce a lack of interest, motivation and understanding of the topics in a given learning activity.

Belsey (2016), pointed to cyberbullying as the use of some ICT tools, social networks, as well as the social behavior of each student or group of students online, in a defamatory manner; that in a deliberate, repetitive, and hostile manner is intended to cause harm to another student.

Contemporary trends pointed out that the validity of the theory of emotional intelligence contributed with new concepts for the knowledge of the personal and emotional aspect of the student, and with it, the possibility of an aid in the management of their emotions, especially in those that lead to aggressive behaviors seeking to reduce violent behaviors.

In the Educational Institution $\mathrm{N}^{\circ} 6064$, the reports of the teachers indicate that the aggressive behavior that the student showed in the classrooms has been transferred to social networks; with verbal attacks, impersonations, expulsion without any reason from the work groups, threats between students, etc. It was observed in these students; inability to resolve a conflict, stress, apathy and limitations for autonomous learning, where the use of metacognition and self-regulation strategies is required to allow them to develop more independent learning in accordance with current needs due to the pandemic.

According to the problem and theory described, the problem formulation includes: general problem: How does emotional intelligence and autonomous learning affect cyberbullying of students at the "Francisco Bolognesi" Educational Institution in Villa el Salvador? as well as the specific problems:

(1) How does emotional intelligence and autonomous learning affect verbal cybervictimization of students at the "Francisco Bolognesi" Educational Institution in Villa el Salvador? (2) How does emotional intelligence and autonomous learning affect cybervictimization visual of the students of the Educational 
Institution "Francisco Bolognesi" of Villa el Salvador ?, (3) How does emotional intelligence and autonomous learning affect the online exclusion of students of the Educational Institution "Francisco Bolognesi" of Villa el Salvador ?, (4) How does emotional intelligence and autonomous learning affect the impersonation of students from the "Francisco Bolognesi" Educational Institution in Villa el Salvador?

In the same way, the study has a theoretical justification, because it allowed the increase of knowledge regarding the cause-and-effect relationship between emotional intelligence and autonomous learning in cyberbullying of students; being based on the theoretical approach of Goleman (1999) regarding emotional intelligence, Muñoz (2006) regarding autonomous learning and Álvarez, et al. (2014) about cyberbullying. It is also justified socially, because the educational community, where the result obtained, will allow decisions to be made to seek alternative solutions to the educational problem described. It is also justified in the methodological aspect, responding to the quantitative approach, performing a statistical analysis with the application of instruments that will be duly validated.

The objectives are the following; general objective: Determine the incidence of emotional intelligence and autonomous learning in cyberbullying of students of the Educational Institution "Francisco Bolognesi" of Villa el Salvador, as well as the specific objectives: (1) Establish the incidence of emotional intelligence and the autonomous learning in the verbal cybervictimization of the students of the Educational Institution "Francisco Bolognesi" of Villa el Salvador; (2) Identify the incidence of emotional intelligence and autonomous learning in visual cybervictimization of students from the "Francisco Bolognesi" Educational Institution of Villa el Salvador, (3) Establish the incidence of emotional intelligence and autonomous learning in the online exclusion of students from the "Francisco Bolognesi" Educational Institution of Villa el Salvador, (4) Identify the incidence of emotional intelligence and autonomous learning in the impersonation of students from the "Francisco Bolognesi" Educational Institution of Villa el Salvador.

On the other hand, the following hypotheses are formulated: General hypothesis: Emotional intelligence and autonomous learning have a significant impact on cyberbullying of students of the "Francisco Bolognesi" Educational Institution in Villa el Salvador, as well as the specific objectives: (1) There is a significant incidence of emotional intelligence and autonomous learning in verbal cybervictimization of students at the "Francisco Bolognesi" Educational Institution in Villa el Salvador; (2) There is a significant incidence of emotional intelligence and autonomous learning in visual cybervictimization of students from the "Francisco Bolognesi" Educational Institution in Villa el Salvador; (3) There is a significant incidence of emotional intelligence and autonomous learning in the online exclusion of students from the "Francisco Bolognesi" Educational Institution of Villa el Salvador and (4) There is a significant incidence of emotional intelligence and autonomous learning in the impersonation of students of the Educational Institution "Francisco Bolognesi" of Villa el Salvador.

\section{Methodology}

\section{Research type and design}

\section{Kind of investigation}

The explanatory study, which, according to Sánchez, et al. (2018), allows the researcher to formulate questions regarding the causes of the phenomenon or event, in the search for the identification of causal relationships between the variables.

The approach was quantitative, which, according to Hernández, Fernández and Baptista (2014), seeks the knowledge and behavior of the fact to be investigated, where quantitative data are collected, with the respective statistical analysis, which will allow to check the formulated hypotheses.

\section{Research design}

The research design was non-experimental, causal correlation, according to Hernández et al. (2014), not experimental, because there was no manipulation of independent variables, and causal correlation, because it allowed to determine the cause-effect relationship of the variable emotional intelligence and autonomous learning in cyberbullying. The scheme is:

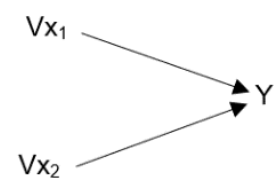


Where:

Note: Excerpted from Hernández

Vx1: Emotional Intelligence

$\mathrm{Vx}$ 2: Autonomous learning

Y: Cyberbullying

\section{Variables and operationalization}

\section{Independent Variable 1: emotional intelligence}

Conceptual definition:

It is the capacity that one has for the identification, expression, and proper management of emotions, as well as for adaptation to situations and proper management of personal interaction with the aim of finding well-being in our lives. (Goleman, 1999)

\section{Operational definition:}

Actions that made it possible to measure the levels of emotional intelligence through its dimensions: mood, intrapersonal intelligence, interpersonal intelligence, adaptability and stress management.

\section{Independent Variable 2: Autonomous learning}

Conceptual definition:

Process to develop a tendency towards formal education, seeking the construction of critical individuals, with their own arguments and feelings, appropriating their own personality development (Rue, 2009).

\section{Operational definition:}

Actions that made it possible to measure the levels of autonomous learning through its dimensions: meta-cognition and self-regulation.

\section{Dependent Variable: Cyberbullying}

Conceptual definition. Violent form that harms more than usual, due to early entry into the virtual world, where the aggression can occur at any time through digital devices, where such attacks negatively influence the victim. (Álvarez et al. 2014)

\section{Operational definition:}

Actions that made it possible to measure the level of cyberbullying in students through its dimensions: verbal cybervictimization, visual cybervictimization, online exclusion, and impersonation. (See Annex)

\section{Population, sample, sampling and unit of analysis}

\section{Population}

The population, according to Carrasco (2013) is the set of elements that belong to a geographic space where the research is carried out, comprised of 133 students in the fifth year of high school from the 6064 Francisco Bolognesi Educational Institution, conformed according to the following table:

Table 1. Distribution of the student population

\begin{tabular}{cccc}
\hline Classroom & Students & Total \\
\hline & H & M & \\
\hline A & 16 & 20 & 36 \\
B & 23 & 11 & 34 \\
C & 14 & 20 & 34 \\
D & 15 & 14 & 29 \\
Total & 68 & 65 & 133 \\
\hline
\end{tabular}

Fountain. Tuition payroll

\section{Inclusion criteria:}

Students of both sexes who are in the fifth year of EBR high school and students of both sexes who have the consent of their parents. 


\section{Exclusion criteria:}

EBR high school students in grades 1-4 and students without the informed consent of their parents.

\section{Show}

The sample according to Carrasco (2013) is a part or portion of the population, which has the same characteristics and properties. It is a representative part, which can also be taken depending on the intention of the study, it includes 99 students of the fifth year of secondary school of the Educational Institution 6064 Francisco Bolognesi, according to the following table (See annex).

\section{Sampling}

The sampling will be probabilistic and stratified, which, according to Boza, et al. (2016) for the proportion, the sample size of a finite population, a sample of 99 students is calculated on 166 students

The sample was distributed among the sections of students in the fifth year of secondary school of the 6064 Francisco Bolognesi Educational Institution, using the proportional stratification coefficient

$$
f h=\frac{n}{N}=\frac{99}{133}=0,7443
$$

Table 2. Distribution of the student sample

\begin{tabular}{cccc}
\hline Classroom & Student & $f h$ & Sample \\
\hline A & 36 & 0,7443 & 27 \\
B & 34 & 0,7443 & 25 \\
C & 34 & 0,7443 & 25 \\
D & 29 & 0,7443 & 22 \\
Total & 133 & 0,7443 & 99 \\
\hline
\end{tabular}

Fountain. Tuition payroll

\section{Analysis unit}

Losada and López (2003) pointed out that they are components observed by the researcher, who then segments them into categories, with defined criteria and through a specific unit. For the purpose of the research, it includes students of the fifth year of secondary school, who come from families with few economic resources, dysfunctional; where parents work more than twelve hours a day; there are some cases of family violence and abuse.

Data collection techniques and instruments

In the study, the survey was used, according to Ander-Egg (2012) it allows the collection of data from the unit of analysis, it can be directly or indirectly.

Likewise, the questionnaire was used and according to Sánchez, et al. (2018) is oriented in the measurement of the behavior of people in specific cases, it is also called a scale, where each of them has a specific value in the sum.

Datasheet 1

Name: BarOn Inventory to Measure Emotional Intelligence

Author: Ugarriza, C.

Adapted by: Loayza, M.

Year: 2020

Description: It comprises 60 items distributed in five dimensions

Time: 20 minutes approx.

Application: individual

Datasheet 2

Name: Self-learning questionnaire

Author: Casas, P. (2019)

Adapted by: Loayza, M.

Year: 2020 
Description: It comprises 26 items, distributed in two dimensions.

Time: 20 minutes approx.

Application: Individual

Datasheet 3

Name: Questionnaire on cyberbullying

Author: Resset, S. and Gamez, M. (2018)

Adapted by: Loayza, M.

Year: 2020

Description: It comprises 26 items, distributed in four dimensions.

Time: 20 minutes approx.

Application: individual

Validity

For Hernández et al. (2014) is the decision-making of methodological and thematic experts, based on criteria such as coherence, clarity and relevance, based on the desired objectives, and the assumptions about what the hypotheses determine. Content validity was performed through expert judgment (See annexes)

Reliability

For Hernández et al. (2014) implies internal or statistical consistency, it is the degree of repetition that an answer has by the same subject, and that produce acceptable results, and because they are polytomous instruments, Cronbach's Alpha coefficient was used. (See annexes)

Procedures

This research has the corresponding authorization from the Director of the Educational Institution. To collect the information, questionnaires were applied, databases were elaborated, tables and statistical figures of frequencies and percentages were elaborated, hypotheses were contrasted, results were analyzed and interpreted, conclusions and recommendations were elaborated.

Data analysis method

A descriptive analysis was carried out, where tables and statistical figures of frequency and percentages were elaborated, and the levels of the variables were determined.

In the same way, an inference analysis was used, where the multivariate test was used and it was processed with the SPSS v.25 software.

Ethical aspects

The study complied with the following ethical principles, taking into account the Declaration of Helsinki:

Respect for the anonymity of the sample participants.

Reference of all the authors who are cited in the research.

Consignment of references according to the APA Standards in its seventh edition.

Respect for the authenticity of the results issued in the data collection.

Consent and Informed Assent.

\section{Results}

\section{Descriptive analysis}

During the development of the study, a statistical analysis of the levels of the variables was carried out, presented in tables and figures of bars of frequencies and percentages.

Table 3. Frequency distribution of the emotional intelligence variable

\begin{tabular}{ccc}
\hline Level & Frequency (fi) & Percentage $(\%)$ \\
\hline Under & 2 & 2,0 \\
Half & 83 & 83,8 \\
High & 14 & 14,2 \\
Total & 99 & 100,0 \\
\hline
\end{tabular}




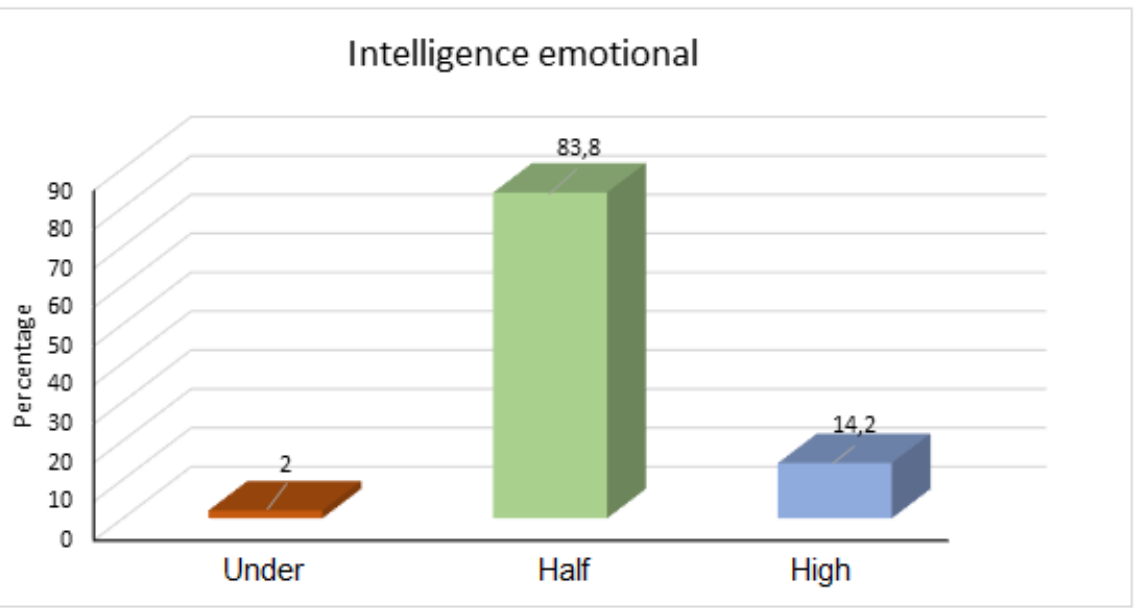

Figure 1. Levels of the variable emotional intelligence

Interpretation. Figure 1 shows that $83.8 \%$ of the students presented a medium level, $14.2 \%$ a high level and $2.0 \%$ a low level; Therefore, it is stated that most of the students presented a medium level of the emotional intelligence variable.

Table 4. Frequency distribution of the autonomous learning variable

\begin{tabular}{ccc}
\hline Level & Frequency (fi) & Percentage (\%) \\
\hline Under & 2 & 2,0 \\
Half & 80 & 80,8 \\
High & 17 & 17,2 \\
Total & 99 & 100,0 \\
\hline
\end{tabular}

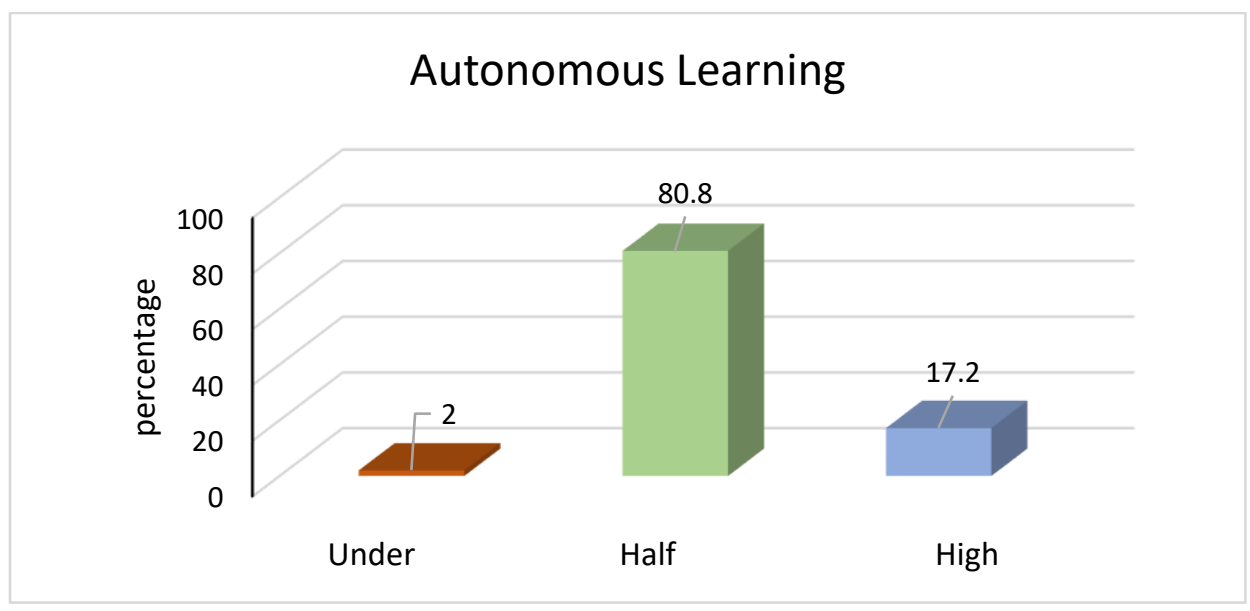

Figure 2 . Levels of the autonomous learning variable

Interpretation. Figure 2 shows that $80.8 \%$ of the students presented a medium level, $17.2 \%$ a high level and $2.0 \%$ a low level; therefore, most students are at a medium level of autonomous learning.

Table 5. Frequency distribution of the verbal-written cybervictimization dimension

\begin{tabular}{ccc}
\hline Levels & Frequency (fi) & Percentage (\%) \\
\hline Under & 6 & 6,1 \\
Half & 90 & 90,9 \\
High & 3 & 3,0 \\
Total & 99 & 100,0 \\
\hline
\end{tabular}




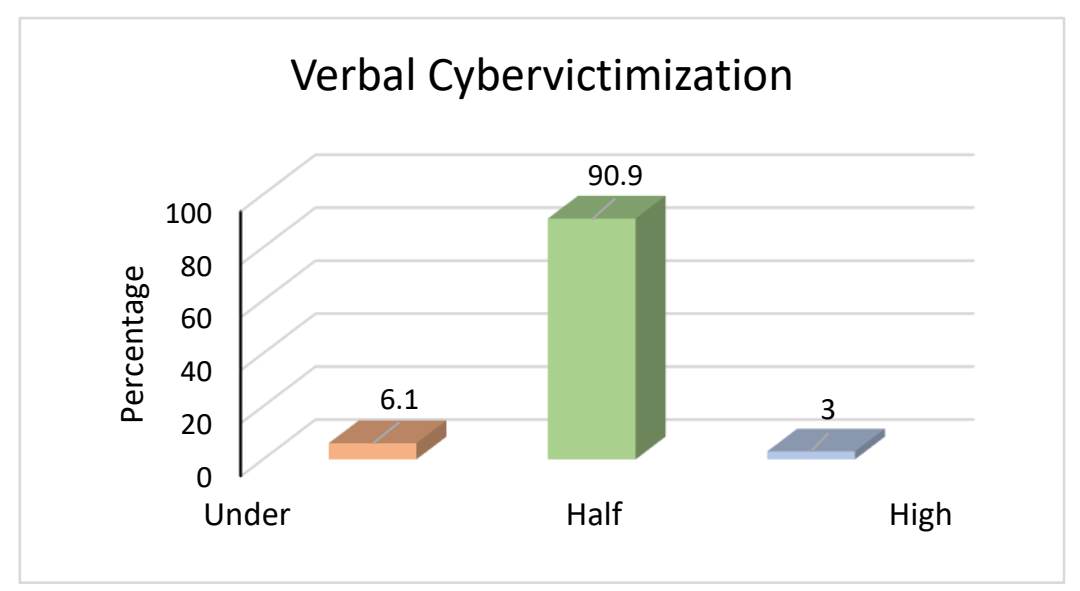

Figure 3. Levels of the Verbal Cybervictimization Dimension

Interpretation: The results of figure 3 show that $90.9 \%$ present a medium level, $6.1 \%$ a low level and $3.0 \%$ a high level; therefore, most of the students present a medium level in the verbal cybervictimization dimension.

Table 6. Frequency distribution of the visual cybervictimization dimension

\begin{tabular}{ccc}
\hline Level & Frequency (fi) & Percentage (\%) \\
\hline Under & 3 & 3,0 \\
Half & 90 & 90,9 \\
High & 6 & 6,1 \\
Total & 99 & 100,0 \\
\hline
\end{tabular}

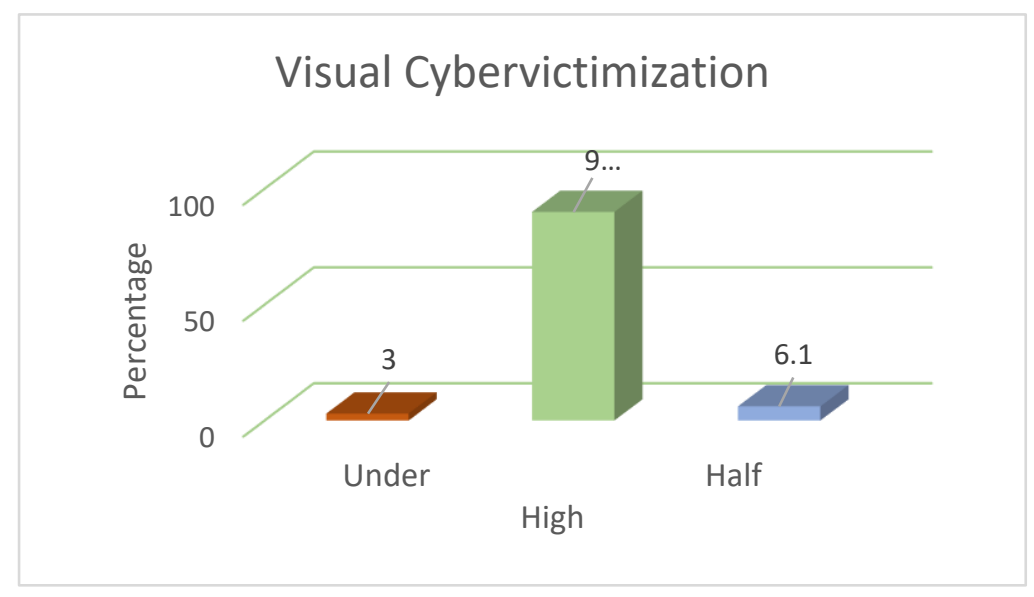

Figure 4. Levels of the visual cybervictimization dimension

Interpretation: The results of figure 4 allow us to observe, $90.9 \%$ present a medium level, $6.1 \%$ a high level and $3.0 \%$ a low level; therefore, most of the students present a medium level in the visual intelligence dimension.

Table 7. Frequency distribution of the online exclusion dimension

\begin{tabular}{ccc}
\hline Level & Frequency (fi) & Percentage (\%) \\
\hline Under & 3 & 3,0 \\
Half & 96 & 97,0 \\
High & 0 & 0 \\
Total & 99 & 100,0 \\
\hline
\end{tabular}




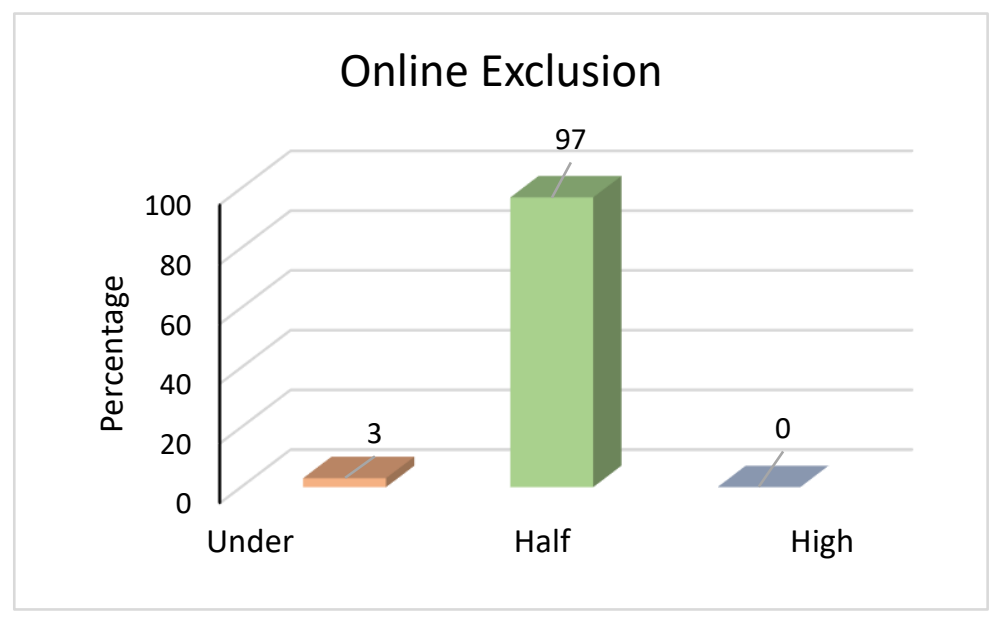

Figure 5. Levels of the online exclusion dimension

Interpretation: The results of figure 5 show that $97.0 \%$ have a medium level, $3.0 \%$ a high level and $0 \%$ a low level; therefore, most of the students present a medium level in the online exclusion dimension.

Table 8. Frequency distribution of the impersonation dimension

\begin{tabular}{ccc}
\hline Level & Frequency (fi) & Percentage (\%) \\
\hline Under & 3 & 3,0 \\
Half & 87 & 87,9 \\
High & 9 & 9,1 \\
Total & 99 & 100,0 \\
\hline
\end{tabular}

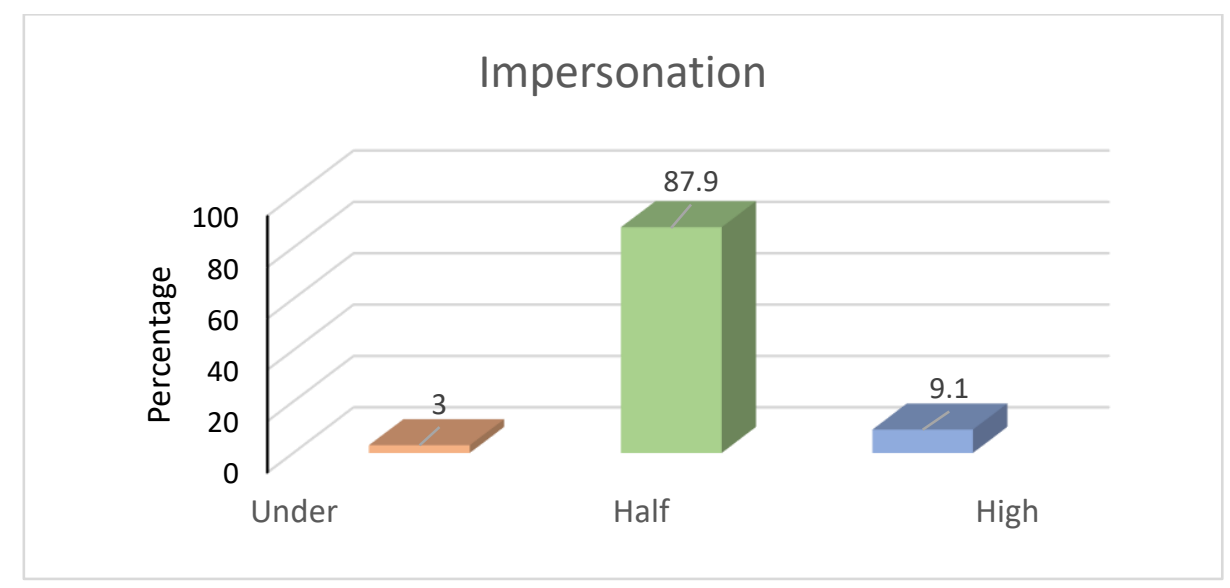

Figure 6. Impersonation dimension levels

Interpretation: The results of figure 6 show that $87.9 \%$ present a medium level, $9.1 \%$ a high level, and $3.0 \%$ a low level; therefore, most of the students present an average level in the impersonation dimension.

Table 9. Frequency distribution of the cyberbullying variable

\begin{tabular}{ccc}
\hline Levels & Frequency (fi) & Percentage (\%) \\
\hline Under & 2 & 2,0 \\
Half & 91 & 91,9 \\
High & 6 & 6.1 \\
Total & 99 & 100,0 \\
\hline
\end{tabular}




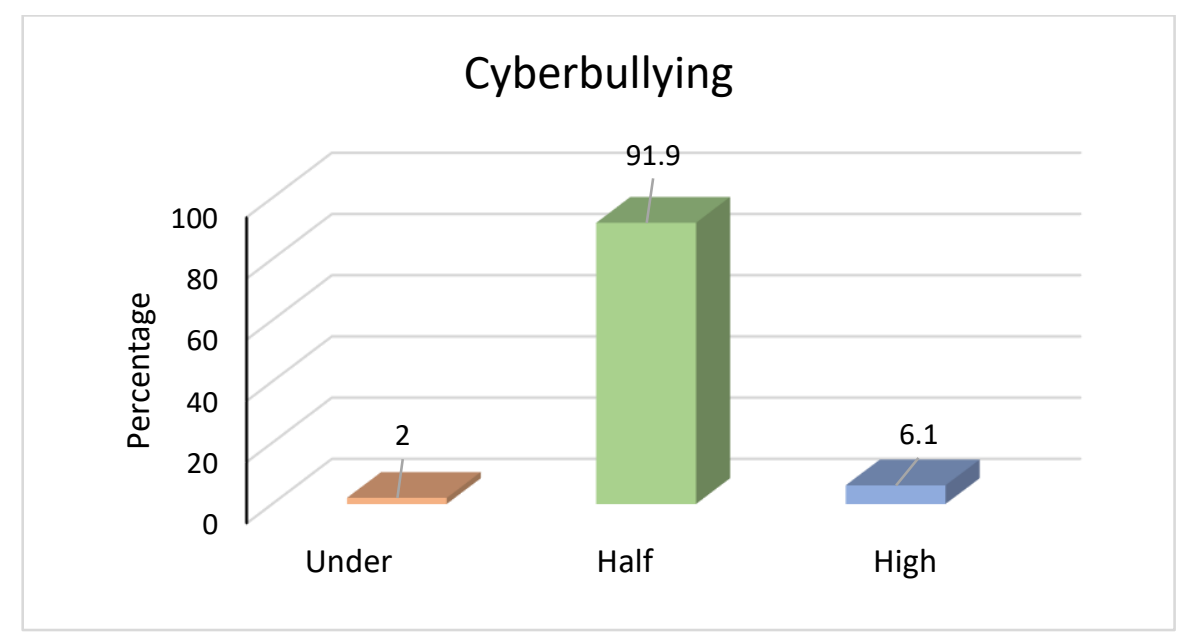

Figure 7. Levels of the cyberbullying variable

Interpretation: Figure 7 shows that $91.9 \%$ of the students present a medium level, $6.1 \%$ a high level and $2.0 \%$ a low level; therefore, most of the students present a medium level in the cyberbullying variable.

\section{Inferential analysis}

General hypothesis

Table 10. Model Summary - General Hypothesis

\begin{tabular}{ccccc}
\hline Model & $\mathrm{R}$ & $\mathrm{R}^{2}$ & $\mathrm{R}^{2}$ ajust & Standard error \\
\hline 1 & $0,624^{\mathrm{a}}$ & 0,389 & 0,376 & 0,264 \\
\hline
\end{tabular}

The model explains that $62.4 \%$, after being corrected for the effect of the sample and the independent variables, is $38.9 \%$, and the typical error of the estimate turns out to be 0.264 .

Table 11. Linear Regression Test - General Hypothesis. ANOVA

\begin{tabular}{ll|c|c|c|c|c}
\hline & Model & Sum of squares & gl & Quadratic mean & F & Sig. \\
\hline 1 & Regression & 4,277 & 2 & 2,139 & 30,585 &, 000 \\
\cline { 2 - 6 } & Residue & 6,713 & 96 & 0,070 & & \\
\hline Total & 10,990 & 98 & & & \\
\hline
\end{tabular}

The F value obtained was 30.585 , where the associated probability $(\mathrm{p}=0.000)$ is less than 0.05 , which leads to rejecting the null hypothesis and accepting the research hypothesis: Emotional intelligence and autonomous learning have a significant impact on cyberbullying of the students of the Educational Institution "Francisco Bolognesi", Villa el Salvador.

\section{Specific hypothesis 1}

Table 12. Model Summary - Specific Hypothesis 1

\begin{tabular}{ccccc}
\hline Model & $\mathrm{R}$ & $\mathrm{R}^{2}$ & $\mathrm{R}^{2}$ ajust & Standard error \\
\hline 1 & $0,066^{\mathrm{a}}$ & 0,004 &,- 016 & 0,347 \\
\hline
\end{tabular}

a. Predictors Learning, Emotional Intelligence

The model explains that $6.6 \%$ that after being corrected for the effect of the sample and the independent variables is $0.4 \%$, likewise, the typical error of the estimate turns out to be 0.347 .

Table 13. Linear Regression Test - Specific Hypothesis 1. ANOVA

\begin{tabular}{|c|c|c|c|c|c|c|}
\hline Model & & Sum of squares & $\mathrm{gl}$ & Quadratic mean & $\mathrm{F}$ & Sig. \\
\hline 1 & Regression & 0,050 & 2 & 0,025 & 0,208 & 0,813 \\
\hline
\end{tabular}




\begin{tabular}{lll|l|l|l}
\hline \hline Residue & 11,586 & 96 & 0,121 & \\
\hline Total & 11,636 & 98 & & \\
\hline
\end{tabular}

The F value obtained was 0.208 , where the associated probability $(\mathrm{p}=0.813)$ is greater than 0.05 , which leads to accept the null hypothesis and reject the research hypothesis: There is no significant incidence between emotional intelligence and learning Autonomous in the verbal cybervictimization of the students of the Educational Institution "Francisco Bolognesi", Villa el Salvador.

\section{Specific hypothesis 2}

Table 14. Model Summary - Specific Hypothesis 2

\begin{tabular}{ccccc}
\hline Model & $\mathrm{R}$ & $\mathrm{R}^{2}$ & $\mathrm{R}^{2}$ ajust & Standard error \\
\hline 1 & $0,227^{\mathrm{a}}$ & 0,052 & 0,032 & 0,344 \\
\hline
\end{tabular}

a. Predictors: (Constant), Learning Emotional intelligence

The model explains that a $22.7 \%$ that after being corrected for the effect of the sample and the independent variables results in $5.2 \%$, likewise, the typical error of the estimate turns out to be 0.344 .

Table 15. Linear Regression Test - Specific Hypothesis 2. ANOVA

\begin{tabular}{lll|c|c|c|c}
\hline Model & & Sum of squares & gl & Quadratic mean & F & Sig. \\
\hline 1 & Regression & 0,621 & 2 & 0,310 & 2,618 & 0,048 \\
\cline { 2 - 7 } & Residue & 11,379 & 96 & 0,119 & & \\
\cline { 2 - 7 } & Total & 12,000 & 98 & & & \\
\hline
\end{tabular}

The F value obtained was 2.618 where the associated probability $(\mathrm{p}=0.048$ ) is less than 0.05 , which leads to rejecting the null hypothesis and accepting the research hypothesis: There is a significant incidence of emotional intelligence and autonomous learning in the visual cybervictimization of the students of the Educational Institution "Francisco Bolognesi", Villa el Salvador.

\section{Specific hypothesis 3}

Table 16. Model Summary - Specific Hypothesis 3

\begin{tabular}{ccccc}
\hline Model & $\mathrm{R}$ & $\mathrm{R}^{2}$ & $\mathrm{R}^{2}$ ajust & Standard error \\
\hline 1 &, $094^{\mathrm{a}}$ &, 009 &,- 012 &, 241 \\
\hline
\end{tabular}

a. Predictors: (Constant)

The model explains that $9.4 \%$ that after being corrected for the effect of the sample and the independent variables results in $0.9 \%$, likewise, the typical error of the estimate turns out to be 0.241 .

Table 17. Linear Regression Test - Specific Hypothesis 3. ANOVA

\begin{tabular}{ll|c|c|c|c|c}
\hline Model & & Sum of squares & gl & Quadratic mean & F & Sig. \\
\hline 1 & Regression &, 050 & 2 &, 025 &, 431 &, 651 \\
\cline { 2 - 7 } & Residue & 5,586 & 96 &, 058 & & \\
\cline { 2 - 7 } & Total & 5,636 & 98 & & & \\
\hline
\end{tabular}

The F value obtained was 0.431 where the associated probability $(\mathrm{p}=0.651)$ is greater than 0.05 , which leads to accept the null hypothesis and reject the research hypothesis: There is no significant incidence of emotional intelligence and autonomous learning in online exclusion in students of the Educational Institution "Francisco Bolognesi", Villa el Salvador.

\section{Specific hypothesis 4}

Table 18. Model Summary - Specific Hypothesis 4

\begin{tabular}{ccccc}
\hline Model & $\mathrm{R}$ & $\mathrm{R}^{2}$ & $\mathrm{R}^{2}$ ajust & Standard error \\
\hline 1 &, $031^{\mathrm{a}}$ &, 001 &,- 020 &, 367 \\
\hline
\end{tabular}




\section{a. Predictors: (Constant), Learning, Emotional Intelligence}

The model explains that $3.1 \%$ that after being corrected for the effect of the sample and the independent variables is $0.1 \%$, also, the typical error of the estimate turns out to be 0.367 .

Table 19. Linear Regression Test - Specific Hypothesis 4. ANOVA

\begin{tabular}{ll|c|c|c|c|c}
\hline Model & & Sum of squares & gl & Quadratic mean & F & Sig. \\
\hline 1 & Regresión &, 013 & 2 &, 006 &, 047 &, 954 \\
\cline { 2 - 7 } & Residuo & 12,897 & 96 &, 134 & & \\
\cline { 2 - 7 } & Total & 5,636 & 98 & & & \\
\hline
\end{tabular}

The $\mathrm{F}$ value obtained was 0.047 where the associated probability $(\mathrm{p}=0.954)$ is greater than 0.05 , which leads to accept the null hypothesis and reject the research hypothesis: There is no significant incidence of emotional intelligence and autonomous learning in the impersonation of students of the Educational Institution "Francisco Bolognesi", Villa el Salvador.

\section{Discussion}

In the general hypothesis, a p-value $=0.000$ in the multivariate test was obtained, which indicates that emotional intelligence and autonomous learning significantly affect cyberbullying, this result is similar to the study by Álvarez (2018) who indicated that there are significant differences according to the sociodemographic profile and that cyberbullying prevails in state schools, where due to remote teaching, it becomes more evident; also García (2018), because the students have an increasingly aggressive behavior, because they did not develop their emotional intelligence thus influencing cyberbullying; and de Peña et al. (2017) who concluded in their study that there is a direct, moderate and significant relationship between emotional intelligence and the resolution of social problems in students, this indicated that students present difficulties in learning and social interrelationships, when they do not develop your emotional intelligence.

Also, with respect to the test of specific hypothesis 1 , with results in the multiple linear regression, with a p-value $=0.813$, it indicates that emotional intelligence and autonomous learning do not significantly affect the verbal cybervictimization of students, this differs from the study by Blanco, et al. (2017), who concluded that there is a relationship between the variables, with a prevalence of the authoritarian parenting style and verbal cybervictimization, that is, the rigidity of training in the family does not allow autonomous learning or the development of intelligence, where the student freely uses a language appropriate to his age; and Estévez (2017), who concluded that there is an inverse and significant relationship between emotional intelligence, aggressive behaviors and the behavior of students at school, where children who have not developed emotional intelligence, become aggressive and they attack their peers with images or drawings related to the victim's personal characteristics when they use social networks; and with the approaches of Álvarez et al. (2014) with an exchange of emails, communication through chats and that implies the reciprocal exchange of insults between several people.

In the specific hypothesis 2 , with a result in the linear regression of $\mathrm{p}=0.048$; which indicates that emotional intelligence and autonomous learning affect students' cyberbullying is similar to the study by Álvarez (2018), thus concluding that there are significant differences according to the sociodemographic profile and that cyberbullying prevails in state schools; as well as Egoeachaga (2017), which concluded that students who have not adequately developed emotional intelligence are prone to visual cybervictimization through icons and photos on social networks; Blanco et al. (2017), pointed out that there is a relationship between the variables, with a prevalence of the authoritarian parenting style and verbal cybervictimization with a $\mathrm{p}=0.028$; so also with the study by Álvarez, et al. (2014), who pointed out that students attack with images of people which are modified, sexual attitudes that damage their integrity, opinions with bad intentions that are written online, and that are made repeatedly.

In the same way, with respect to the test of specific hypothesis 3 , with a $p=0.651$, it indicates that emotional intelligence and autonomous learning do not significantly affect the online exclusion of students; This result differs from the study by García (2018), where students with greater use of virtual environments through remote teaching have developed their emotional intelligence and have become more autonomous and avoid conflicts with their peers in the use of social networks, there are no virtual fights between them due to the prevalence of maintaining a certain leadership through chat and email; and the proposals of Álvarez et al. (2014), where it is 
indicated that online exclusion takes place when the person or persons do not allow the victim to participate within a specific social network, being something that students have managed to manage through an autonomous learning of the rules of coexistence that are being carried out through remote teaching, so that students make better use of virtual environments.

Finally, regarding specific hypothesis 4 , with a result $p=0.954$ in the multiple linear regression test, it indicated that emotional intelligence and autonomous learning do not significantly affect cyberbullying; and it differs from the study by Peña et al. (2017), who affirmed the existence of a direct, moderate and significant relationship between emotional intelligence and the resolution of social problems in students; This would indicate a high level of impersonation, as well as Egoeachaga (2017), who concluded that students have assimilated in a good way the use of social networks with a greater participation in remote education, therefore there is greater respect for their classmates; and it coincides with the approach of Álvarez et al. (2014) who stated that, when there is no adequate emotional intelligence, students take the place of another whom we call a victim, using their access password to enter social networks; or sending subliminal, offensive and aggressive messages to other people.

\section{Conclusions}

First: Emotional intelligence and autonomous learning had a significant impact on cyberbullying of students from the "Francisco Bolognesi" Educational Institution, Villa el Salvador; having obtained a result in the linear logistic regression test a $\mathrm{p}$-value $=0.000$.

Second: Emotional intelligence and autonomous learning did not significantly affect the verbal cybervictimization of students from the "Francisco Bolognesi" Educational Institution, Villa el Salvador; having obtained as a result in the linear logistic regression test a $\mathrm{p}$-value $=0.813$.

Third: Emotional intelligence and autonomous learning did not have a significant impact on visual cybervictimization of students from the "Francisco Bolognesi" Educational Institution, Villa el Salvador; having obtained a result in the linear logistic regression test a $\mathrm{p}$-value $=0.048$.

Quarter: Emotional intelligence and autonomous learning had a significant impact on the online exclusion of students from the "Francisco Bolognesi" Educational Institution, Villa el Salvador, having obtained a result in the linear logistic regression test a $\mathrm{p}$-value $=0.651$.

Fifth: Emotional intelligence and autonomous learning had a significant impact on the impersonation of students from the "Francisco Bolognesi" Educational Institution, Villa el Salvador; having obtained a result in the linear logistic regression test a $\mathrm{p}$-value $=0.954$.

\section{References}

[1]. Aebli, H. (2001). Factores de la enseñanza que favorecen el aprendizaje autónomo.

[2]. Aftab, P. (2018). What is Cyberbullying? Recuperado de http://aftab.com/index.php?page=cyberbullying.

[3]. Alvarado, A. (2017). Inteligencia emocional para desarrolladores. https://medium.com/@agalvary8/inteligencia-emocional-para-desarrolladores-43cdd9957b5d.

[4]. Álvarez et al. (2014). Risk factors associated with cyber victimization in adolescence. International Journal of Clinical and Health Psychology 15(3), 226-235. https://doi.org/10.1016/j.ijchp.2015.03.002

[5]. Álvarez, J. (2020). Estilo parental y ciberbullying en adolescentes del distrito de Laredo. [Tesis doctoral, Universidad César Vallejo de Perú].

[6]. Ander-Egg, E. (2012). Técnicas de investigación social. Madrid: Paidós.

[7]. Arnaiz, P. et al. (2016). Online addiction behaviors and cyberbullying among adolescents. Anales de Psicología 32(3), 761-769 https://doi.org/10.6018/analesps.32.3.217461

[8]. Bandura, A. (1973). Aprendizaje social. México: Trillas.

[9]. Bar-On, R. (2009). The Emotional Quotient (EQ-I): A Test of Emotional Intelligente. Toronto: MultiHealth Systems.

[10]. Belsey, B. (2016). Cyberbullying: A real and growing threat. ATA Magazine, 88(1), 14-18, 20-21.

[11]. Berkowitz (1964). Agressive cues in agressive behavior and hostility catarsis. Psichology Review (71), 104-122.

[12]. Binet, A. \& Simón, T. (1905). Méthodes nouvelles pour le diagnostic du niveau intellectuel des anormaux. L'Année Psychologique, (11), 191-244. 
[13]. Blanco, M.et al. (2017). Estilos de crianza que inciden en la presencia de ciberbullying en un colegio público de Bucaramanga. Revista virtual de la Institución Universitaria de Envigado, 11(18)

[14]. Brofenbrenner, U. (1987). La ecología del desarrollo humano: experimentos en entornos naturales y diseñados. Barcelona: Paidós-Ibérica.

[15]. Buelga, S. (2020). Cyberbullying among adolescents: Psychometric properties of the cyb-ags cyberaggressor scale. International Journal Environmental Reserach Public Health (17) 3090.

[16]. https//10.3390/ijerph17093090.

[17]. Cardozo, G. et al. (2017). Bullying and ciberbullying: A comparative study with school adolescents. Revista Mexicana de Psicología 34(2), 101-109

[18]. Carrasco, S. (2013.). Metodología de investigación científica. Pautas metodológicas para diseñar y elaborar el proyecto de investigación. Lima: Editorial San Marcos

[19]. Casas, P. (2019). Competencia docente y aprendizaje autónomo en estudiantes del Instituto de Educación Superior Tecnológico Salesiano de Breña - Lima, 2017. [Tesis. Universidad Nacional de Educación Enrique Guzmán y Valle, La Cantuta, Chosica, Perú]

[20]. Catell, (1971). The theory of fluid and cristallized intelligence. British Jornal of Educational Pschycology (37) 204-209

[21]. Cuadrado, I. \& Fernandez, I. (2014). Cyberspace as a generator of changes in the aggressive-victim role. Computers in Human Behavior. (36), 225-233. https://doi.org/10.1016/j.chb.2014.03.070

[22]. Diaz, F. \& Hernández, G. (2010). Estrategias docentes para un aprendizaje significativo. Una interpretación constructivista. México, D.F.: Mc Graw Hill.

[23]. Dollard, J. \& Miller, N. (1939). Frustration and agression. New Haven, CN: Yale University Press.

[24]. Egoeachaga, C. (2017). Inteligencia emocional y la convivencia escolar en estudiantes del tercer grado de secundaria de la Institución Educativa Ciro Alegría, Carabayllo-2017. Universidad César Vallejo, Lima, Perú.

[25]. Estévez, et al. (2019). La Influencia del bullying y el ciberbullying en el ajuste psicológico de víctimas y agresores en la adolescencia. Revista Internacional de Investigación Ambiental y Salud Pública 16(12).

[26]. https://doi.org/10.3390/ijerph16122080

[27]. Fierro, C. \& Carbajal, P. (2019). Convivencia Escolar: Una revisión del concepto. Psicoperspectivas. 18(1), 9-27. http://dx.doi.org/10.5027/psicoperspectivas-vol18-issue1-fulltext-1486.

[28]. Freud, S. (1920). Beyoud the preasure principle. Nueva York: Bantam books.

[29]. Galvez, J. et al. (2016). Adolescent victimization through mobile phone and internet scale: Psychometric examination in chilean students. Revista Iberoamericana de Diagnóstico y Evaluación Psicológica 1(41), $16-27$

[30]. García, J. (2008). La educación emocional, su importancia en el proceso de aprendizaje. Educación, $36(1), 1-24$

[31]. García, E. (2018). The influence of emotional intelligence on aggressive behavior. [Tesis doctoral, Universidad de España.]

[32]. Dennehy, R. et al. (2020). Progress in the modeling of cyberbullying from the perspective of the human language technologies. CEUR Workshop Proceedings, (51), 1-12. https://doi.org/10.1016/j.avb.2020.101379

[33]. Goleman, D. (1999). Intelligence emotional. Barcelona: Kairós.

[34]. Guilford, J. (1967). The nature of human intelligence. Nueva York: Mac Graw Hill

[35]. Larrañaga, E. et al. (2018). Socio-cognitive and emotional factors on perpetration of cyberbullying. Comunicar 26(56), 19-28. https://doi.org/10.3916/C56-2018-02

[36]. Hernández. et al. (2014). Metodología de la investigación. México: Mc Graw-Hill.

[37]. Lorenz, K. Z. (1965). Evolution and modification of behavior. Chicago: University of Chicago Press.

[38]. Losada, R. \& López, J. (2003). Métodos de investigación en ciencias humanas y sociales. Madrid: Paraninfo.

[39]. Martinez, M. et al. (2018). Cyberbullying, aggressiveness, and emotional intelligence in adolescence. International Journal of Environmental Research and Public Health 16(24).

[40]. https://doi.org/10.3390/ijerph16245079

[41]. Oquelis, J. (2017). Diagnóstico de inteligencia emocional en estudiantes de educación secundaria. [Tesis, Universidad de Piura, Perú.]

[42]. Peña, et al. (2017). Las competencias emocionales: material escolar indispensable en la mochila de la vida. Revista Padres y Maestros (368) 6-10

[43]. Piaget, J. (1983). Seis estudios de psicología. Madrid: Morata.

[44]. Ortega, et al. (2017). School violence and attitude toward authority of students perpetrators of cyberbullying. Revista de Psicodidáctica 22(1), 23-28. https://doi.org/10.1016/S1136-1034(17)30040-0 
[45]. Prats, M. et al. (2018). Design and application of educational workshops for the healthy use of the internet and online social networks in adolescents: Description of a pilot study.

[46]. https://doi.org/10.12795/pixelbit.2018.i52.08

[47]. Resnick, L.et al. (1991). Perspectives on socially shared cognition. Washington, DC: American Psychological Association.

[48]. Resset, S. \& Gamez, M. (2018). Psychometric properties of cyberbullying questionnaire in an argentinean sample. Universitas Psychologica, (17), 5.

[49]. Romera, E. et al. (2016). Cyberbullying: Social competence, motivation and peer relationships. Comunicar 24(48), 71-79. https://doi.org/10.3916/C48-2016-07

[50]. Rosal, H. et al. (2018). Una mirada más profunda a la detección del ciberacoso en las redes sociales. Actas de la Conferencia conjunta internacional sobre redes neuronales.

[51]. Rué, J. (2009). El aprendizaje autónomo en educación superior. España: Narcea, S. A. de Ediciones.

[52]. Sánchez, H.et al. (2018). Manual de términos en investigación científica, tecnológica y humanística. Lima: Universidad Ricardo Palma

[53]. Segura, et al. (2020). Empatía e inteligencia emocional en adolescentes ciberagresores y cibervíctimas. Revista Internacional de Investigación Ambiental y Salud Pública 17(13), 1- 14

[54]. https://doi.org/10.3390/ijerph17134681

[55]. Spearman, Ch. (1927). Nature of intelligence and the principles o cognition. Londres: McMillan.

[56]. Terman L. M. (1975). Measurement of intelligence. Boston: Houghton Millin.

[57]. Thurstone, L. (1960). Nature of Intelligence. London: Kegan, Paul \& Trench, CO

[58]. Trigoso, M.et al. (2014). Estudio intercultural de la inteligencia emocional y variables psicoeducativas a través del surveymonkey. International Journal of Developmental and Educational Psychology INFAD Revista de Psicología, 4(1), 403-414. https://doi.org/10.17060/ijodaep.2014.n1.v4.859

[59]. Talpur, K. et al. (2020). Cyberbullying detection: Current trends and future directions. Journal of Theoretical and Applied Information Technology 98(16), 3197-3208

[60]. Prats et al. (2018). Design and application of educational workshops for the healthy use of the internet and online social networks in adolescents: Description of a pilot study. Píxel-Bit. Revista de Medios y Educación. (52) ISSN: 1133-8482. http://dx.doi.org/10.12795/pixelbit.2018.i52.08

[61]. Ugarriza, C. (2003). Inventario para medir inteligencia emocional de BarOn. Persona, (4), 129-160. Universidad de Lima.

[62]. Van Hee, et al. (2018) Detección automática de ciberacoso en el texto de las redes sociales. PLoS ONE 13 (10): e0203794. https://doi.org/10.1371/journal.pone.0203794

[63]. Vernon, P. (1971). The structure of human abilities. Londres: Metluen.

[64]. Yot, C. et al. (2019). Trainee teachers' perceptions on cyberbullying in educational contexts. Social Sciences 8(1),21. https://doi.org/10.3390/socsci8010021

[65]. Zych, I. et al. (2016). Cyberbullying: A systematic review of research, its prevalence and assessment issues in Spanish studies. Psicologia Educativa 22(1), 5-18 https://doi.org/10.1016/j.pse.2016.03.002

[66]. Sánchez, C. (2020). Ejemplos de Referencias Bibliográficas APA. Normas APA (7ma edición). https://normas-apa.org/referencias/ejemplos/ 